2. Aхберово C.A. Cmygeнцова И.A., Менgелеви" A.M. у $g p / /$ Казан. меА. журн. - 1994. - № 2 . C. $128-132$.

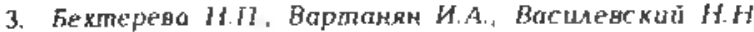
Механизмы деятельности моэа челорека. - $\Lambda$; Наука. 1983. - 4. 1 - 67 ? $\mathrm{C}$

4 Вмптокиї А.С. Анагностика разнития и тедоло гичегкан кимника трудного Аетгтвы. Хрестоматия по патопсихолпгя. -- M, 1981. - С. 66-80

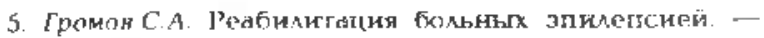
А.: Меднация 1987. - 176 с

6. Ермолина А.А //Журн. невропатол. и пеихистр. 1980 - No 3. C 439-443.

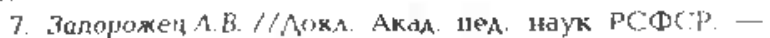
1962. - № 1. - C.77- 80
8. Саркисон С.А. Структуріпе осноны Аеятельностн мozrd. - M.: Медиџина, $1980 .-295$ с.

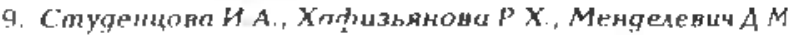
u gр. Сиособ коррекіци иттемектуально мнғстичаских

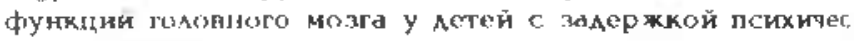
кото разиттия. - М., 1992.

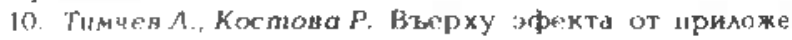

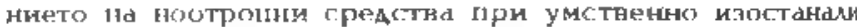

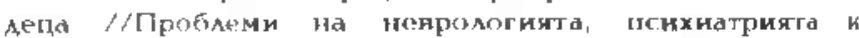
гверохирургнята - София, 1981. - № 9. - С 90-94

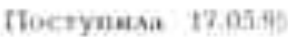

У

\title{
B.B. Honomapea
}

\section{ДИАГНОСТИКА И ЛЕЧЕНИЕ СИНДРОМА МИЛЛЕРА-ФИНЕРА}

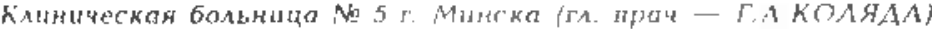

$\sin$

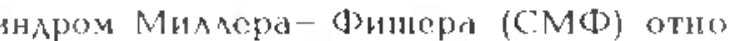

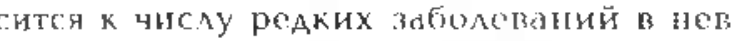

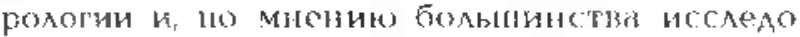

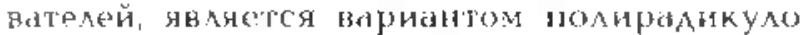

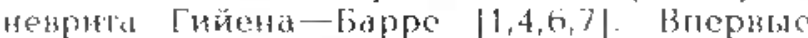

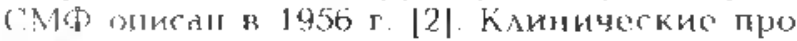
яіздения (ММ) составлякт сочетание атак гны, арефлексии и офтальмонлеяин. K' ғас. 'оянему времени доказана аутоиммунная прицида болезни [3]. Ряа анторов считает 8озможным грямой эффек' воздействия ммкроорганизмов на нерннук ткене [5] $B$ natoreneas СМФ больпун роль, играет ви.

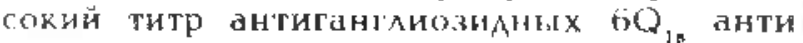
тел, веАущий $\mathrm{K}$ тотере ацетилхолина из терминалей Авигательных нервов $[3,8,9]$ Морфололически ири С.М наблюадется демиелинизация как периферической, так и центральной нервной система |I!

Практические невропатологи мало зна комы с СМФ, позтому сго Аиагностика ока зынается залозділой, а лечение неадекнат ним, что ведет к хронизации процесса. От сутствие в русскоязычной литературе оюи Сания Полобного синдрома побулияо при вести АВа собственных наблюдсния больных CMD.

Н а 6 я юАен и е 1. Больной 3., 52 лет, направлен в кинику с жаяббами на Авоение в глазах, наруитение глотания, речи, шаткость Походки. Болен 8 мес, когда й фоне острого респираторното заболенания впердые появиось Авокияе в глазах, онемекие и парестезии В конечностях, Шаткость похоАКн. Аеqиася В соОтвет ствии с Анагнозом. наруиение мозгового кровообрd щения в вертебрально-базиярном бассейне. В связи с прогресскруюцим нарушением походхи заподозрена опуходь Задней черепной ямки. Неврологический ста тус: множественный нистагм с межъядерной офталь моплегией, ограничение отведения гмазных яблок в сторонг, Аисфагия, грубая Аизартрия. Парезов нет. Коленные и ахиловы рефлексы отсутствуют. Полинев ритический тип расстройства чунствитедьности в форие "носкон" и "перчаток". Грубо расстросно мh

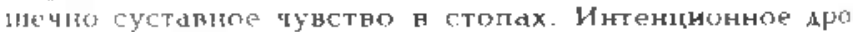
*ание и мимопопадағие при выполнении коорайани

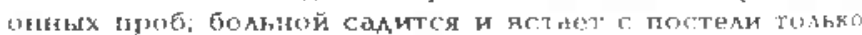

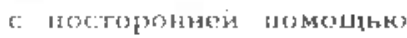

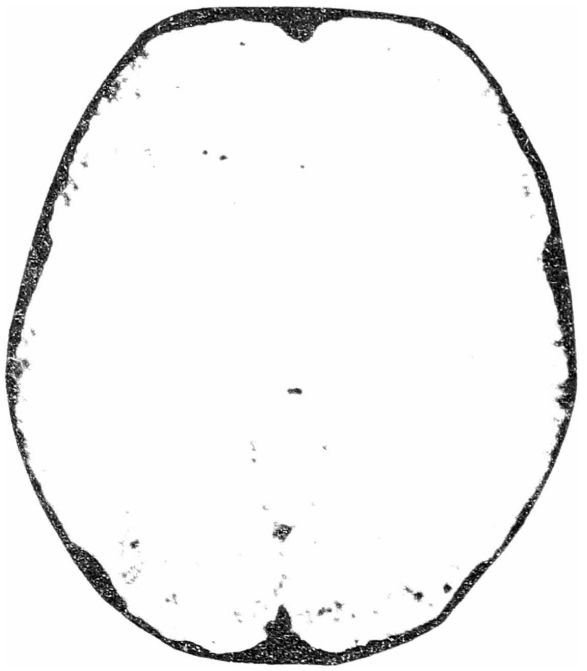

Комгвктерная томография больного 3. Анффузные гидроцефально атрофические изменения

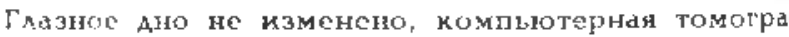
фия лоловного мозта выявияа гиАроцвфально атрофи ческие изиенения (рнсунок), 8 сиинномозгоной жия

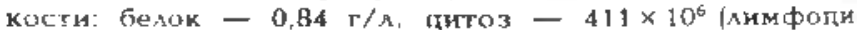
тарный), гахар - 2.8 ммоль/л. Циркулирующие нммунапе комплексы (ЦЦLK) - 60.8 мл/мк (норма $123,5-174,2 \mathrm{M \mu r} / \mathrm{MA})$ уронень трансамкназ 1,05 $\mathrm{r} / \mathrm{s}$ (норма - $0.3 \mathrm{r} / \mathrm{A}$ ). Остальные биохимическне и обине анализы крови н мочи в норме. Скорость проведения имдуяса [СПИ] по Авигательным волокнам малобер поного нерна с днух сторон сннхена Ап $37,2 \mathrm{M} / \mathrm{C}$, большеберданого - $40.0 \mathrm{M} / \mathrm{C}$, амгінтуа М-ответа $0,4-0,6$ мВ. После назначенкя прєднизолона (первона

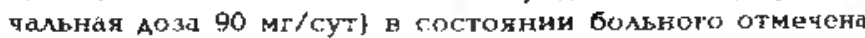
положителькая Аинамика: улучпияись рөчь и глотание. уменьшияась степен выраженности координаторнах 
нарушений, наметились коленные и ахимоны рефяек сы. больной стал самостоятеяьно сияеть, вставать, СПИ увеличияась АО 43.5-46.0 м/C, амллитуаа М ответа возросла до $0,6-0,8 \mathrm{mB}$.

Н а блю а е и е 2. Больной У., 34 лет, ростуши в киякику с жалобами на снижение зрения, Авоенме, нарушеняе походки. онемение мевой кисти. Болен 2 мес: после простуаното заболевания снизилось зре ние и опустилось верхнес неко слева. Лечияся по

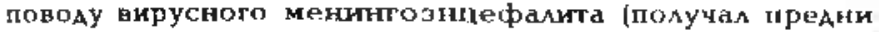
золон $60 \mathrm{mr} /$ сут. антибиотикн) без зффекта. Невроло гнческий статус: эрачкн иирокне, зрачконие реакиии на свет вялые, Анусторониий птоз расходяцееся косоглазне. Объем Аннжений ГАазнзх яблок ограничен во нсе стороны, особенно вверх. Множесгненный нистагм с межъядерной офтаяьмоплетией. Парезя хонечвостей нет. Сухожилынlе и периосталиные рефлексы на руках симжены, коденные и ахимовы живыс, Гипестезия н левой қисти, гиперестезия в столах. Мышечно сустанное чунство сохранело. Интен ционное Арожание н мимопопадание ири ныпсілнении КоорАинационных цроб. Похолка атактическая

Зрение резко снижено (счет пальцен у мида). На глазном Ане qастичная атрофия эрительных нсраян При комшьютеряой томографии голонного мозга обиа ружена умеренная ннутрешия гидроцефалия. В лик воре Белок $0,6 \mathrm{TN} / \mathrm{s}$, цито $351 \times 10^{6}$, сахар $2,2 \mathrm{mmosh} / \mathrm{s}$ ЦИК - 81,0 мкг/мА. трансаминазы $1,05 \mathrm{l} / \mathrm{A}$, остальные похазатели и общий анализ крови без особенгостей. СПИ. малоберповын̆ нерв - $47.0 \mathrm{~m} / \mathrm{c}$. бомшеберцовьий $47.4 \mathrm{~m} / \mathrm{C}_{1}$ амтлитуа $\mathrm{M}$ ответа $-1.5 \mathrm{MB}$. После назна чењия преднизолона в Аозе 140 мг по пульснрукпцей схеме у больното восстановился объем движений глаз щых яблок, уменшынась стеген нирлженности нис тагма и зтаксии. СПИ увелнчнлас. А( $52-55$ м/с, ам плитуас М ответа - АO 2,1 $\mathrm{MH}$.

Таким образом, у больных выявлена́ классическая триала симптомов СМФ: атаксия, офтальмоплегия и дрефлексия. ОАнако в обоих случаях эти нарушеняя нмеАи свои особенности. У больного 3 . атаксия носила комбинированный характер (сочетание сенситивной и мозжечковой), во втором наблюдении атаксия была только мозжечковой. У первого больного имелась наружная офтальмоплегия, у второго тотальная. Арефлексия у больного У. была только со стороны верхних конечностей, хотя отмечено снижение СПИ на ногах. Кроме того, у этого пациента паблюдалась атрофия зрительного нерва. В обоих случа ях компьютерная томография выявила гиАро цефально-атрофические изменения, в лик воре - белково клеточная Аиссоциация с лимфоцитарным плеоцитозом у первого больного. Снижение уровня ЦИК у обоих болыных свиАетельствовало о хроническом характере процесса.

Аечение СМФ заключается в назначе нии аАекватной Аозы кортикостероидов (90-140 мг/сут). В Аитературе описан поло жительный результат применения ниүтри венных иммуноглобулинов (АОза $0,4 \mathrm{Mr} / \mathrm{Kг}$ массы) и плазмафереза

Приведенные наблюАения Показали, что СМФ складывается из сочетания атаксии, офтальмоплегии и арефлексии, кажАый из этих симптомон может иметь клинические псобенности. Кроме этой триады, при СМФ по- виАимому, Может наблюдаться и атро фия зоительных нернов. Течение болезни мопофазное, Iрогрсанентное. Неалекнат ная терапия способствует хронизации про Ifeccis.

\section{AUTEPATYPA}

1. Ferrer $X$, Ellie E., Zarniviere et al. //J. Neurol. Newros. Psych. - 1993. - Vol. 56. - P. 698-699.

2. Fisher M. //Eng. J. Med. - 1956. - Vol. 255. p. $57-67$.

3. Jibiki T., Shrnizu N., Terashima J., Yuki N. //Rinsto Sninkeidakō. - 1994. - Vol. 34. - P. 381-384.

4. Kaiser Smith Barone //J. Neurol. Neuros. Psych 1989. - Vol. 52. -- P. $402-803$.

5. Ortuno A.b. Naerty C. Munor J. et at. //J. Neurol Nelusos. Psych - 1990. - Vol. 53 - P. 615 -616.

6. Petty R.K., Duncan R., Jamal G.A. et at. //J. Neorol Nesuros. Psyrh. - 1493. - Vol. 56. - P. 201-203.

7. Ping-Rung Jip //J. Neurol. Neuros. Psych. - 1991. Vol. 54. - P. 1121

8. Roberis $M$, Willison H. Vincent A. et al. //Lancet. 1994. - Vol. 343. - P. 454-455.

9. Willison H.J., Veitch J., Faterson G. ef al. //J. Neorol Neuros. Psych. - 1993. - Vol. 56. - P. 204-206.

Rocryanan 28:04tas 